\title{
ANALISIS KEBIJAKAN PENGGUNAAN PUKAT IKAN DI PERAIRAN ZONA EKONOMI EKSKLUSIF INDONESIA SAMUDERA HINDIA
}

\author{
Ali Suman \\ Peneliti pada Balai Riset Perikanan Perairan Umum-Mariana, Palembang \\ Teregristrasi I tanggal: 6 Pebruari 2007; Diterima setelah perbaikan tanggal: 26 Maret 2008; \\ Disetujui terbit tanggal: 25 April 2008
}

\begin{abstract}
ABSTRAK
Dalam rangka pemanfaatan sumber daya ikan demersal yamg optimal bagi peningkatan devisa dan pengembangan wilayah, maka dikeluarkan Keputusan Menteri Pertanian No.770/Kpts/IK.120/10/1996 tentang penggunaan pukat ikan di perairan Zona Ekonomi Eksklusif Indonesia. Untuk melihat sampai sejauh mana mutu dan efektivitas kebijakan ini, maka dilakukan analisis input, proses, output, dan dampak terhadap kebijakan tersebut. Hasil analisis menunjukkan bahwa kebijakan penggunaan pukat ikan perlu ditinjau kembali dan disarankan sebaiknya untuk dicabut. Hal ini berkaitan dengan tidak terealisirnya dampak yang diinginkan dalam kebijakan tersebut, sementara yang timbul justru dampak yang tidak diinginkan. Selain itu, kebijakan ini akan mendorong timbul illegal, unreported, and unregulated serta konflik sosial di tingkat nelayan.
\end{abstract}

KATA KUNCl: Samudera Hindia, fish net, analisis kebijakan

\section{ABSTRACT: A policy analysis of using fish net in the Indonesian EEZ of Indian Ocean. By: Ali Suman}

The agriculture ministrial decree of No.770/Kpts/IK.120/10/1996 on the use of fish net was passed in order to optimally utilized demersal fish resource to raise export earnings and trigger regional development. An input, process, output, and impact approach was exerted to evaluate the quality of the decree. It was found that the decree should be revoked as the targeted impacts of the decree were not achieved. The decree, on the other hand, tended to bring about negative impacts such as unexpected illegal fishing and social unrest among small fishermen.

KEYWORDS: Indian Ocean, fish net, policy analysis

\section{PENDAHULUAN}

Pembangunan perikanan dilakukan melalui upaya peningkatan produktivitas dan efisiensi usaha yang pada gilirannya diharapkan dapat meningkatkan produksi perikanan yang diarahkan untuk meningkatkan konsumsi, penerimaan devisa dan penyediaan bahan baku industri dalam negeri. Peningkatan produksi tersebut sekaligus diupayakan untuk meningkatkan pendapatan petani nelayan, kesempatan kerja, kesempatan berusaha serta mendorong pertumbuhan industri dalam negeri dan pertumbuhan daerah. Semua hal tersebut dilakukan dengan tetap memperhatikan kelestarian sumber daya dan lingkungan hidup dalam rangka mewujudkan pembangunan perikanan yang berkelanjutan dan berwawasan lingkungan. 
Indonesia merupakan negara kepulauan yang memiliki luas perairan laut terbesar di antara negara-negara Asia serta memiliki garis pantai terpanjang di dunia. Potensi perikanan yang demikian besar belum dimanfaatkan secara optimal, sehingga perlu berbagai kebijakan untuk mendorong tercapai pemanfaatan yang optimal tersebut. Keputusan Menteri Pertanian No.770/Kpts/ IK.120/10/96 tentang penggunaan pukat ikan untuk pengusahaan ikan demersal di Zona Ekonomi Eksklusif Indonesia Samudera Hindia pantai barat Nangroe Aceh Darussalam, merupakan salah satu upaya untuk mengoptimalkan pemanfaatan sumberdaya ikan tersebut. Makalah kebijakan ini disusun untuk melihat sampai sejauh mana mutu dan efektitivitas kebijakan tersebut.

Bahan yang digunakan dalam analisis kebijakan ini adalah Surat Keputusan Menteri Pertanian No.770/Kpts/IK.120/10/ 96 yaitu tentang penggunaan pukat ikan di Zona Ekonomi Eksklusif Indonesia Samudera Hindia, di samping itu juga dilengkapi dengan undang-undang, peraturan pemerintah, Keppres, dan peraturan lainnya, sebagai bahan tambahan dalam melakukan analisis kebijakan. Analisis yang dilakukan dalam melihat mutu dan efektivitas kebijakan digunakan analisis input, proses, output, dan dampak (Nikijuluw, 1999).

Tabel 1. Analisis input, proses, output, dan dampak terhadap Keputusan Menteri Pertanian No.770/Kpts/IK.120/10/96

Table 1. IPRI analysis to The Agriculture Ministrial Decree of No.770/Kpts/IK.120/ $10 / 1996$

\begin{tabular}{|c|c|c|c|c|}
\hline \multirow{2}{*}{$\begin{array}{c}\text { Kebijakan/ } \\
\text { Policy }\end{array}$} & \multicolumn{2}{|c|}{ AksilActions } & \multicolumn{2}{|c|}{ Konsekuensi/Qonsequncies } \\
\hline & Input/Input & Proses/Proceses & Hasil/Results & Dampak/Impacts \\
\hline $\begin{array}{l}\text { Keputusan Menteri } \\
\text { No.770/Kpts/IK. } \\
\text { 120/10/96 tentang } \\
\text { penggunaan pukat } \\
\text { ikan di Zō̄̄ā } \\
\text { Ekonomi Ekslusif } \\
\text { Indonesia }\end{array}$ & $\begin{array}{l}\text { - Potensi sumber } \\
\text { daya ikan demersal } \\
\text { yang besar } \\
\text { - Pemanfaatan belum } \\
\text { optimal } \\
\text { - Menghidupkan kota } \\
\text { Sabang } \\
\text { - UU No.5/83 } \\
\text { - UU No.9/85 } \\
\text { - PP No.15/84 } \\
\text { - PP No.15/90 } \\
\text { - Keppres 44/74 } \\
\text { - Keppres 15/84 } \\
\text { - Keppres } 96 / \mathrm{M} / 93 \\
\text { - SK Mentan } \\
\text { No.815/Kpts/ } \\
\text { IK.120/11/90 } \\
\text { - SK Mentan } \\
\text { No.816/Kpts/ } \\
\text { IK.120/11/90 } \\
\text { - SK Mentan } \\
\text { No.96/Kpts/ } \\
\text { OT.120/94 } \\
\text { - Keputusan Rapat } \\
\text { Pimpinan Deptan tgl } \\
\text { 26/9/1996 }\end{array}$ & $\begin{array}{l}\text { - Izin hanya pada } \\
\text { kapal perikanan } \\
\text { kayu ukuran >80 GT } \\
\text { dan mesin lebih } \\
\text { besar dari } 300 \text { DK } \\
\text { - Tali ris bawah tidak } \\
\text { boleh pakai rantai } \\
\text { penggugah } \\
\text { - Ukuran mata jaring } \\
\text { >5 cm } \\
\text { - Kantong jaring atas } \\
\text { tidak boleh rangkap } \\
\text { - Registerasi kapal } \\
\text { akurat } \\
\text { - Pangkalan di } \\
\text { pelabuhan PT. PSB } \\
\end{array}$ & $\begin{array}{l}\text { Penggunaan pukat } \\
\text { ikan di perairan } \\
\text { Zona Ekonomi } \\
\text { Ekslusif Indonesia } \\
\text { Samudera Hindia } \\
\text { perairan barat } \\
\text { Sumatera pada } \\
\text { posisi } 4^{\circ} \text { LU } 96^{\circ} \mathrm{BT}\end{array}$ & $\begin{array}{l}\text { - Pemanfaatan } \\
\text { sumber daya ikan } \\
\text { demersal yang } \\
\text { optimal } \\
\text { - Penurunan } \\
\text { produksi nelayan } \\
\text { skala kecil } \\
\text { - Meningkatkan } \\
\text { konflik sosial } \\
\text { - Meningkatkan } \\
\text { kesenjangan } \\
\text { - Meningkatkan } \\
\text { illegal, unreported, } \\
\text { and unregulated } \\
\text { - Pengusahaan tidak } \\
\text { berkelanjutan }\end{array}$ \\
\hline
\end{tabular}


Untuk mengkaji kebijakan pemerintah yang tertuang dalam Surat Keputusan Menteri Pertanian tersebut, maka dilakukan analisis kebijakan dengan pendekatan analisis input, proses, output, dan dampak secara normatif (Nikijuluw, 1999). Secara rinci analisis input, proses, output, dan dampak disajikan pada Tabel 1.

\section{Input}

Dari input yang terdapat pada Tabel 1 dikatakan bahwa terdapat potensi sumberdaya ikan demersal yang besar di perairan Zona Ekonomi Eksklusif Indonesia pada pantai barat Nangroe Aceh Darussalam pada kordinat $4^{\circ} \mathrm{LU}-96^{\circ} \mathrm{BT}$. Melihat lokasi penangkapan yang diproyeksikan merupakan perairan laut dalam, adalah tidak logis dan tidak berdasar untuk mengatakan bahwa perairan tersebut memiliki potensi ikan demersal yang besar. Hasil penelitian Mc Manum (1996) mengatakan bahwa perairan Samudera Hindia pada sebelah barat Sumatera memiliki kelimpahan tinggi pada perairan dangkal, sedang pada perairan di atas 100 $\mathrm{m}$ kelimpahannya cenderung rendah. Selanjutnya, Bianchi (1996) mengatakan bahwa kelimpahan ikan demersal yang tinggi terdapat pada kedalaman $30 \mathrm{~m}$ ke bawah dan makin menurun seiring dengan bertambahnya kedalaman. Widodo et al. (1998) juga mengatakan bahwa perairan dangkal dengan kondisi dasar yang relatif rata dan substrat berlumpur atau lumpur berpasir sampai kedalaman $100 \mathrm{~m}$ merupakan daerah penangkapan sumberdaya ikan demersal. Dengan demikian, maka pernyataan dalam input keputusan ini merupakan pernyataan yang tidak logis dan tidak didasarkan pada kaidah ilmiah yang dapat dipertanggungjawabkan. Pernyataan tersebut cenderung dipaksakan dan hanya bertujuan untuk mendukung penggunaan pukat ikan yang merupakan nama trawl yang disamarkan agar tidak menyalahkan aturan yang sudah ada yaitu Keppres No.39/1980. Dengan demikian, terlihat dari awal bahwa kebijakan ini sudah berangkat dari ketidakjujuran ilmiah, sehingga dalam aplikasinya juga akan menyebabkan banyak permasalahan-permasalahan.

Selanjutnya, apabila ditinjau dari perkembangan perikanan di pantai barat Aceh, terlihat indikasi bahwa daerah tersebut tidak potensial untuk perikanan demersal. Sampai saat ini pemanfaatan sumberdaya ikan yang berkembang adalah perikanan pelagis dengan hasil tangkapan yang dominan berupa ikan cakalang dan tongkol (Bahar \& Badrudin, 1992), sementara perikanan demersal hanya terbatas pada perikanan skala kecil di Aceh Barat (Badrudin, 1978; Suman, 1997). Dasar perairan yang dangkal di pantai barat Aceh ini juga sebagian besar berkarang dan hanya sedikit yang merupakan wilayah yang layak trawl.

Input lain yaitu berupa perkembangan kota Sabang dengan berkembangnya perikanan demersal di perairan Zona Ekonomi Eksklusif Indonesia tersebut menjadi tidak logis, mengingat potensi sumberdaya ikan demersal yang kecil tersebut adalah tidak mungkin menarik investor untuk melakukan investasi pada kegiatan perikanan yang jelas tidak berkembang. Sebagaimana diketahui bahwa pengusaha dan nelayan yang bergerak dalam penangkapan ikan demersal pada umumnya berpangkalan di Kota Medan. Daerah penangkapan armada tersebut adalah di perairan Selat Malaka yang potensial untuk ikan demersal. Dengan potensi yang baik tersebut, maka investasi untuk kepentingan pemanfaatan ikan demersal berkembang dengan cepat di Kota Medan. Oleh karena itu, apabila ingin mengembangkan Kota Sabang dalam 
kaitannya pengusahaan ikan demersal di perairan Zona Ekonomi Eksklusif Indonesia barat Nangroe Aceh Darussalam, didasari terlebih dahulu oleh potensi sumberdaya ikan demersal yang melimpah. Dengan kondisi input yang tidak sahih dan tidak jujur, maka pengembangan Kota Sabang tersebut hanya menjadi utopia. Atau dengan kata lain dapat dikatakan bahwa pengaruh pengusahaan sumberdaya ikan demersal tersebut tidak akan membawa dampak apaapa terhadap Kota Sabang.

\section{Proses}

Dari segi proses pada Tabel 1, terlihat bahwa kebijakan ini sangat memperhatikan aspek kelestarian sumberdaya. Dikatakan bahwa kapal yang boleh menggunakan pukat ikan mempunyai ukuran lebih besar dari 80 GT dan ukuran mesin lebih besar dari 300 DK. Dengan adanya batasan ini diharapkan armada pukat ikan tidak akan melakukan penangkapan ke daerah jalur I, karena akan kesulitan dalam operasinya. Selain itu, juga pukat ikan tersebut memiliki ukuran jaring kantong yang lebih besar dari $5 \mathrm{~cm}$, tali ris bawah tidak boleh memiliki alat penggugah dan kantong jaring bagian atas tidak boleh rangkap. Adanya batasan ini juga sangat mendukung kelestarian sumberdaya, karena akan lebih menjamin kesinambungan rekruitmen dengan tetap memberi kesempatan pada ikan untuk berkembang sehingga akan menjamin tersedianya populasi pengganti.

Hal yang agak kurang diperhatikan dalam proses ini adalah belum terjaminnya prinsip keadilan dalam berusaha. Dengan ukuran armada yang begitu besar, maka hanya nelayan pengusaha yang dapat berinvestasi di sektor ini, sementara nelayan kecil hanya dapat menonton. Dengan begitu, ada kesan seolah-olah kebijakan ini hanya diorientasikan pada nelayan pengusaha (perikanan skala industri) dan bukan pada nelayan skala kecil. Terlihat juga adanya nuansa konspirasi yang terbentuk antara nelayan pengusaha dan instansi terkait yang berusaha untuk melegalkan alat tangkap yang dilarang. Dengan adanya legitimasi tersebut, maka dengan berlindung di balik izin ini, maka nelayan pengusaha akan dapat memanfaatkan ikan demersal di perairan mana saja di wilayah Indonesia. Fenomena ini terlihat dari makin sering konflik antara nelayan tradisional dan nelayan pukat ikan di sepanjang pantai timur Sumatera, akibatnya operasi penangkapan pukat ikan yang menjarah semua daerah penangkapan ikan demersal. Analisis komposisi hasil tangkapan pukat ikan mengindikasikan bahwa alat tangkap tersebut melakukan penangkapan bukan di wilayah Zona Ekonomi Eksklusif Indonesia, tetapi di perairan teritorial terutama di sekitar pantai (Tim Pengkajian Pengoperasian Pukat Ikan di Zona Ekonomi Eksklusif Indonesia Selat Malaka, 1999; Sumiono et al., 1998).

Sebagai konsekuensi logis dari lemahnya pengawasan dan penegakkan hukum dikatakan bahwa hampir semua ketentuan yang ada pada keputusan tersebut dilanggar. Sebagian besar (50\%) dari armada pukat ikan melanggar ukuran kapal (<80 GT), ukuran mata kantong yang digunakan juga lebih kecil serta daerah penangkapan dilakukan di perairan teritorial pengoperasian pukat ikan di Zona Ekonomi Eksklusif Indonesia Selat Malaka. Dengan demikian, makin jelas bahwa kebijakan tersebut hanya digunakan sebagai alasan untuk melegitimasi nelayan pengusaha untuk menangkap ikan demersal dengan pukat ikan yang sebenarnya adalah nama lain dari trawl.

Analisis lebih lanjut pada proses dikatakan bahwa pangkalan armada juga di pelabuhan Perikanan Samudera Besar. Ketentuan ini juga menjadi tidak logis, 
karena dampak memindahkan seluruh armada yang sudah eksis dari Medan ke kota Sabang. Pekerjaan tersebut bukan hal mudah, bahkan boleh dibilang sangat mustahil. Hal ini mengingat pelabuhan di kota Medan sudah mapan dalam penyediaan sarana dan prasarana pengusahaan ikan demersal dibanding dengan pelabuhan PT. Perikanan Samudera Besar yang sangat minim fasilitas pendukungnya. Belum lagi kemampuan $\mathrm{PT}$. Perikanan Samudera Besar dalam membantu pengembangan perikanan demersal, mengigat fokus utama penangkapannya adalah periapan pelagis besar. Adalah merupakan dua hal yang berbeda dalam strategi mengembangkan pemanfaatan sumberdaya ikan demersal dan ikan pelagis di suatu wilayah. Hal lain yang juga berbeda adalah latar belakang budaya yang menjadi perhatian besar apabila memindahkan suatu komunitas nelayan. Akan terjadi berbagai benturan budaya apabila pemindahan tersebut dipaksakan dan selanjutnya akan menimbulkan konflik sosial yang penuh dengan kerawanan-kerawanan.

Selain itu, dengan ditunjuknya pelabuhan PT. Perikanan Samudera Besar sebagai pangkalan akan menimbulkan monopoli dalam pengadaan sarana dan prasarana penangkapan ikan, begitu juga akan memperpanjang jalur birokrasi yang ada. Dengan latar belakang yang demikian, maka pangkalan di pelabuhan PT. Perikanan Samudera Besar menjadi tidak menarik sehingga pada umumnya seluruh armada perikanan pukat ikan sampai saat ini tetap berpangkalan di tangkahan pemilik pukat (tauke) di Belawan, Medan (Sumiono et al., 1998; Tim Pengkajian Pengoperasian Pukat Ikan di Zona Ekonomi Eksklusif Indonesia Selat Malaka, 1999). Hal yang patut menjadi pertimbangan yang sangat sering, yaitu bahwa PT. Perikanan Samudera Besar sendiri sudah dilikuidasi dan pelabuhan yang dimaksud sudah tidak berfungsi seperti sebelum.

\section{Hasil (Output)}

Hasil dari kebijakan ini adalah diizinkannya penggunaan pukat ikan untuk menangkap ikan demersal di perairan Zona Ekonomi Eksklusif Indonesia Samudera Hindia perairan barat Sumatera sekitar Nangroe Aceh Darussalam dengan batas kordinat $4^{\circ} \mathrm{LU}$ dan $96^{\circ} \mathrm{BT}$. Karena input yang tidak valid, maka dalam pelaksanaannya hampir tidak ada nelayan pukat ikan yang mengadakan penangkapan di wilayah tersebut. Penangkapan tetap terpusat di perairan teritorial Selat Malaka bahkan sudah menjangkau pantai timur Sumatera seperti perairan Jambi dan Sumatera Selatan dan Kepulauan Riau. Dengan kondisi yang demikian, menjadi lebih jelas lagi bahwa keputusan ini dipakai sebagai tameng legalisasi alat tangkap trawl untuk menangkap ikan demersal di perairan Indonesia.

Hal lain yang perlu dipertanyakan adalah ketidakkonsistenan dasar hukum penggunaan pukat ikan di Zona Ekonomi Eksklusif Indonesia pada kordinat $4^{\circ} \mathrm{LU}$ dan $96^{\circ}$ BT. Sampai saat ini dasar hukum diizinkannya penggunaan pukat ikan di Zona Ekonomi Eksklusif Indonesia Selat Malaka hanya didasarkan pada surat tertanggal 16 Pebruari 1990 dari Direktorat Jenderal Perikanan pada Gubernur Sumatera Utara, Panglima Armada Barat, dan Ketua Umum Himpunan Nelayan Seluruh Indonesia. Surat No.IK.120/ DJ.1266/2/90K tersebut pada awalnya mengizinkan 60 buah kapal untuk melakukan penangkapan ikan di Zona Ekonomi Eksklusif Indonesia Selat Malaka. Akibat adanya gejolak sosial dari masyarakat nelayan, maka intervensi Pangdam I Bukit Barisan sebagai ketua BAKORSTANASDA, melakukan 
penambahan pukat ikan yang beroperasi menjadi 80 buah kapal, termasuk 15 kapal milik Yayasan ABRI (Mitra Oceano Abadi Perkasa).

Dengan ada Keputusan Menteri Pertanian ini, surat Direktorat Jenderal Perikanan menjadi gugur atau lebih disempurnakan. Tetapi karena saling tidak terkordinasi mengakibatkan dasar hukum legalisasi pemanfaatan sumber daya ikan demersal dengan pukat ikan di wilayah yang relatif berdekatan memiliki 2 sumber hukum. Akibatnya, pengusahaan tidak rasional karena tidak terkontrol lagi penangkapan. Pukat ikan yang mengantongi izin penangkapan di zona ekonomi eksklusif Indonesia pantai barat Nangroe Aceh Darussalam tetap melakukan penangkapan di perairan teritorial Selat Malaka dan pantai timur Sumatera, begitu juga kapal ikan yang mengantongi izin penangkapan di zona ekonomi eksklusif Indonesia Selat Malaka tetap akan melakukan penangkapan di wilayah yang sama. Penangkapan pada 2 wilayah yang berbeda, ditambah lagi dengan armada ilegal dari negara tetangga mengakibatkan perairan Selat Malaka menjadi wilayah penangkapan yang penuh konflik serta terancam kelestarian sumber daya ikan demersal. Pada akhir-akhir ini konflik semakin banyak terjadi dengan sering dibakar armada pukat ikan oleh nelayan tradisional. Begitu pula dengan nelayan pukat ikan yang melanggar kewilayahan penangkapan, sering menabrak dan merusak armada perikanan tradisional.

Analisis lebih lanjut menunjukkan bahwa dengan ada 2 dasar kebijakan ini justru yang paling diuntungkan adalah nelayan pengusaha karena dengan mudah dapat mengantongi izin pada 2 perairan yang berbeda, walaupun dalam pelaksanaan penangkapan dilakukan pada wlayah yang sama maupun wilayah lain yang potensial sumber daya ikan demersal.

Selanjutnya keputusan ini mengalami perubahan dengan keputusan Menteri Pertanian No.1039.I/Kpta/IK.120/10/1999. Perubahan keputusan tersebut hanya menambah pangkalan armada pukat ikan yaitu Pelabuhan Perikanan Nusantara Sibolga. Perubahan ini juga tidak logis karena mengkaitkan pemanfaatan sumber daya ikan demersal dengan pukat ikan di zona ekonomi eksklusif Indonesia pantai barat Nangroe Aceh Darussalam dengan pangkalan armada di Pelabuhan Perikanan Nusantara Sibolga. Sebagaimana diketahui bahwa pemanfaatan sumber daya ikan demersal dengan pukat ikan di perairan zona ekonomi eksklusif Indonesia barat Nangroe Aceh Darussalam tersebut tidak berkembang, oleh karena itu tidak memerlukan tambahan pangkalan untuk armada. Dengan demikian, terlihat ada kepentingan tertentu yang mengaitkan kebutuhan Pelabuhan Perikanan Nusantara Sibolga dengan perkembangan pemanfaatan ikan di zona ekonomi eksklusif Indonesia. Tetapi yang jelas Pelabuhan Perikanan Nusantara Sibolga selama ini menjadi pangkalan armada trawl yang beroperasi di pantai barat Sumatera Utara, Sumatera Barat, dan Bengkulu. Oleh karena itu, penggunaan keputusan Menteri Pertanian untuk melegalisasi alat tangkap yang terlarang terulang kembali, karena dengan dilegalkannya Pelabuhan Perikanan Nusantara Sibolga menjadi pangkalan armada pukat ikan (trawl), maka tidak terlihat lagi ada pelanggaran peraturan di pelabuhan tersebut. Dengan demikian, semua alat tangkap trawl yang berpangkalan di Pelabuhan Perikanan Nusantara Sibolga menjadi legal karena menggunakan nama pukat ikan. 


\section{Dampak}

Dampak yang diinginkan dari kebijakan ini adalah:

1. Pemanfaatan sumberdaya ikan demersal yang optimal.

2. Peningkatan devisa.

3. Pengembangan wilayah.

Apabila ditelaah lebih lanjut terlihat dampak yang diinginkan tersebut tidak ada yang tercapai. Berawal dari ketidakbenaran input, maka sampai saat ini belum ada nelayan yang mengusahakan sumber daya ikan demersal di perairan Zona Ekonomi Eksklusif Indonesia pantai barat Nangroe Aceh Darussalam. Dengan demikian, maka pemanfaatan sumberdaya tidak optimal dan peningkatan devisa dari pengusahaan ini juga tidak terealisasi. Begitu juga pengembangan wilayah Kota Sabang sebagai dampak pengusahaan ikan demersal yang berkembang hanya menjadi konsep. Dan apabila ditinjau lebih mendalam justru beberapa dampak negatif yang timbul yaitu:

1. Menurunkan produksi nelayan skala kecil.

2. Meningkatkan konflik sosial.

3. Meningkatkan kesenjangan sosial.

4. Meningkatkan illegal, unreported, and unregulated.

5. Pengusahaan tidak berkelanjutan.

Dengan adanya kebijakan yang tumpang tindih, maka dasar izin penggunaan pukat ikan menjadi dua sumber dan juga meliputi dua wilayah, yaitu Zona Ekonomi Eksklusif Indonesia Selat Malaka dan Zona Ekonomi Eksklusif Indonesia pantai barat Nangroe Aceh Darussalam. Tetapi mengingat kedua wilayah perairan Zona Ekonomi Eksklusif Indonesia tersebut tidak potensial untuk pemanfaatan ikan demersal, maka semua armada penangkapan pukat ikan yang dikeluarkan izin tersebut beroperasi di perairan teritorial Selat Malaka dan pantai timur Sumatera. Karena wilayah perairan tersebut merupakan daerah penangkapan ikan demersal oleh nelayan tradisional, maka akan mengakibatkan penurunan jumlah hasil tangkapan nelayan tradisional akibat sumber daya tersebut telah habis dikuras oleh nelayan pukat ikan. Dampak selanjutnya adalah akan meningkatkan konflik sosial yang mengakibatkan terjadi permusuhan dan saling merusak antara nelayan pukat ikan dan nelayan tradisional. Dengan semakin menurunnya hasil tangkapan nelayan tradisional, maka akan semakin menurunkan pendapatan dan konsekuensi logisnya akan menimbulkan kesenjangan yang semakin lebar antara nelayan pengusaha dan nelayan skala kecil.

Dampak lain yang tidak diinginkan dengan adanya kebijakan tersebut adalah masuknya armada trawl dari negara tetangga untuk melakukan pencurian ikan di wilayah perairan Indonesia. Dengan berlindung pada legalisasi pukat ikan (trawl), maka armada-armada negara tetangga masuk secara legal dan ilegal dengan armada pukat ikan Indonesia yang berizin, sehingga pencurian ikan menjadi tidak terdeteksi (Tim Pengkajian Pengoperasian Pukat Ikan di Zona Ekonomi Eksklusif Indonesia Selat Malaka). Dengan pengusahaan armada yang saling tumpang tindih tersebut mengakibatkan pemanfaatan sumberdaya ikan demersal di wilayah tersebut menjadi tidak berkelanjutan.

\section{REKOMENDASI DAN SARAN}

1. Keputusan Menteri Pertanian No. $770 /$ Kpts/IK.120/10/96 ditinjau kembali dan disarankan sebaiknya dicabut oleh Departemen Kelautan dan Perikanan. Hal ini melihat kondisi obyektif yang ada, di mana dari semua dampak yang ingin dicapai kebijakan tersebut tidak 
ada satu pun yang terealisir, sementara yang signifikan adalah munculnya dampak yang tidak diinginkan. Selain itu, kebijakan ini menjadi legitimasi alat tangkap yang dilarang penggunaannya sesuai dengan Keppres No.39/1980.

2. Agar tidak menginjak rasa keadilan dalam usaha penangkapan ikan, maka suatu kebijakan jangan dibuat berorientasi parsial. Pemberian izin alat tangkap yang terlarang di suatu wilayah dengan sendiri menimbulkan kecemburuan sosial pada daerah lainnya yang dilarang penggunaan alat tangkap tersebut. Akibat lebih lanjut, maka wilayah lain tersebut juga akan mengintrodusir alat tangkap yang sama berupa pukat ikan (trawl) walaupun tidak ada legalisasi, dan pada akhirnya akan menimbulkan kesenjangan dan konflik sosial yang berkepanjangan.

\section{DAFTAR PUSTAKA}

Badrudin. 1978. Studi pendahuluan tentang umur, pertumbuhan, sex ratio, dan kematangan ovari udang windu (Penaeus monodon Fabricius) di perairan Meulaboh, Aceh Barat. Prosiding Seminar II Perikanan Udang. 135-144.

Bahar, S. \& Badrudin. 1992. Tingkat pemanfaatan sumber daya ikan pelagis di perairan pantai utara Daerah Istimewa Aceh. Jurnal Penelitian Perikanan Laut. 65: 41-48.

Bianchi, G. 1996. Demersal fish assembles of trawlable ground of northwest Sumatera. ICLARM Stud. Rev. 23: 123130.
Mcmanus, J. W. 1996. Marine bottom fish communities from the Indian Ocean coast of Bali and to mid Sumatera. ICLARM Studi Rev. 23: 91-101.

Nikijuluw, V. P. H. 1999. Bahan Kuliah Analisis Kebijakan Perikanan Tangkap. Program Studi Teknologi Kelautan. Program Pasca Sarjana. Institut Pertanian Bogor. Bogor.

Suman, A. 1997. Status perikanan udang di perairan Aceh Barat. Prosiding Konvensi Nasional Benua Maritim. Ujung Pandang. Dewan Ketahanan NasionalBadan Pengkajian dan Penerapan Teknologi.

Sumiono, B., J. Soselisa, \& M. Rijal, 1998. Perikanan udang di Selat Malaka. Jurnal OCTOPUS. 2 (1) July: 95-103.

Tim Pengkajian Pengoperasian Pukat Ikan di ZEEI Selat Malaka. 1999. Kajian Pengoperasian Pukat lkan di Perairan Zona Ekonomi Eksklusif Indonesia Selat Malaka. Direktorat Jenderal Perikanan. Departemen Pertanian. Jakarta. 75 pp.

Widodo, J., K. A. Aziz, B. E. Priyono, G. H. Tampubolon, N. Naamin, \& A. Djamali. 1998. Potensi dan penyebaran sumber daya ikan laut di perairan Indonesia. Komisi Nasional Pengkajian Stok Sumber Daya Ikan Laut. Lembaga IImu Pengetahuan Indonesia. Jakarta. Indonesia. 